\title{
KONSTRUKSI MAKNA BUDAYA ISLAM \\ PADA MASYARAKAT ACEH
}

\author{
Rasyidah \\ IAIN Ar-Raniry Banda Aceh \\ Jl. Ar-Raniry No. 1, (+62-651)-52921, Darussalam, Banda Aceh 23111 \\ E-mail: rasyidah_safii@yahoo.co.id \\ HP. +62-85260123074
}

Abstract: This paper explores the culture of Islam that is practiced in rural communities in Aceh. Cultural practices are carried from generation to generation. This paper uses Berger viewpoint associated with externalizing, internalizing, and objectification that is synergistic with the Herbert Blumer's theory of symbolic interactionist to see the reality of meaning. The results shows that the cultural practice is still running strong today due to the construction of the three pillars of an active role in this community, namely 1) the construction process through intergenerational value transfer, 2) meunasah or mosque as a center for media uniformity of meaning that construct and maintain a common meaning, and 3) social feedback as the binding effect of community participation.

Abstrak: Tulisan ini mengeksplorasi budaya Islam yang dipraktikkan masyarakat di pedesaan Aceh. Praktik budaya yang dilakukan dari generasi ke generasi. Tulisan ini menggunakan sudut pandang Berger terkait dengan eksternalisasi, internalisasi, dan objektifikasi yang sinergis dengan teori interaksionis simbolik Herbert Blumer untuk melihat realitas makna. Hasil penelitian menunjukkan bahwa praktik budaya yang masih berjalan kuat hingga saat ini disebabkan dengan tiga pilar konstruksi yang aktif berperan dalam komunitas ini. Tiga peran konstruksi tersebut adalah 1) proses konstruksi melalui transfer nilai antargenerasi, 2) meunasah atau masjid sebagai sentra media penyeragaman makna yang membangun dan mempertahankan common meaning, dan 3) feed back sosial sebagai effect yang mengikat partisipasi masyarakat.

Kata Kunci: Praktik Budaya, Aceh, masjid, budaya Islam, meunasah. 


\section{A. Pendahuluan}

Kabupaten Aceh Besar terletak di bagian barat Provinsi Aceh yang menempati posisi paling ujung dari Pulau Sumatera, tepatnya pada koordinat 5,2-5,8 derajat Lintang Utara dan 95-95,8 derajat Bujur Timur. Dalam Bahasa Aceh, kabupaten ini disebut Aceh Rayeuk (Aceh Besar), ada juga yang menyebutnya Aceh Lhee Sagoe (Aceh Tiga Segi). Selain itu, ada juga yang menyebutnya dengan Aceh Inti (Aceh Proper), atau Aceh sebenarnya, karena daerah inilah pada mulanya yang menjadi inti Kerajaan Aceh atau ibukota Kerajaan Aceh.

Sebagai daerah pesisir, Aceh Besar memiliki akses yang luas bagi pengaruh berbagai budaya. Beberapa catatan sejarah menunjukkan tentang transformasi orientasi budaya yang terjadi di daerah ini. Transformasi pertama berawal dari arus besar orientasi budaya Hindu. Van Langen merinci pengaruh India di Aceh terutama dalam sorotannya mengenai pemakaian bahasa-bahasa Sansekerta yang telah dipergunakan dalam istilah-istilah kekeluargaan, sastra, nama-nama binatang, pertanian, logam dan permata, perangkat dan gelar, perkakas rumah, beserta musik dan seni suara. Di daerah ini juga terdapat bangunan masjid yang berdiri di atas pondasi yang tinggi yang diduga pondasi tersebut merupakan kaki candi yang mirip dengan candi-candi Budha di Jawa (Iskandar, 1972: 2-12).

Selanjutnya, orientasi budaya Islam menjadi dominan di wilayah Aceh Besar. Hal ini dapat dideteksi melalui kerajaan-kerajaan Islam yang ada di daerah ini. Hasil Seminar tentang sejarah masuknya Islam di Indonesia yang bertempat di Banda Aceh 1978, merumuskan: "kerajaan-kerajaan Islam yang pertama adalah Perlak, Lamori, dan Pasai” (Ibrahim dan Sufi, 1987: 397).

Wilayah ini menjadi wilayah inti pada masa kerajaan Aceh Darussalam yang memiliki keterkaitan warisan budaya yang erat dengan praktik budaya hari ini. Kesinambungan waktu dari sejak kerajaan besar ini dan kedekatan wilayah menjadikan Aceh Besar sebagai salah satu daerah yang sangat kental mengamalkan warisan budaya. Meski seiring waktu yang berlalu ratusan tahun, pengamalan ini mengalami perubahan.

Tulisan ini bertujuan mengungkap tentang konstruksi makna praktik budaya Islam pada masyarakat perdesaan Aceh Besar. Perdesaan sebagai karakteristik wilayah ditetapkan dengan pertimbangan bahwa di perdesaan lebih banyak praktik budaya yang masih diamalkan dibandingkan dengan wilayah perkotaan. Mereka masih memegang budaya Islam sebagai konsep dalam kehidupan bermasyarakat. 


\section{B. Teori Konstruksi Makna}

Berbagai praktik budaya yang masih dijalankan merupakan bagian dari bukti kuatnya kesepahaman masyarakat terhadap makna makna ritual yang dilaksanakannya. Konstruksi makna terhadap praktik budaya ini menjadi bagian yang sangat penting dalam bertahannya warisan budaya ini.

Berger menyebutkan bahwa kenyataan sosial adalah hasil eksternalisasi, internalisasi, dan objektivasi manusia terhadap pengetahuan dalam kehidupan sehari-sehari. Atau, secara sederhana, eksternalisasi dipengaruhi oleh cadangan pengetahuan (stock of knowledge) yang dimilikinya. Cadangan pengetahuan adalah akumulasi dari pengetahuan akal (common sense knowledge) manusia dan masyarakat.

Eksternalisasi, objektifikasi, dan internalisasi yang diketengahkan oleh Beger ini, senada dengan apa yang dimaksudkan oleh Blumer dengan teori interaksi simbolisnya. Menurut Blumer (May dan Powell, 2008: 77) "The responses of human beings to their environments are mediated by meaningful interpretations." Manusia merancang perbuatannya. Perbuatannya tidak bersifat semata-mata reaksi biologi at as kebutuhannya, perat uran kelompoknya, seluruh situasinya, melainkan merupakan konstruksinya (Veerger, 1983: 225). Interaksionis-simbolis bertumpu pada tiga premis yaitu: 1) Manusia bertindak terhadap sesuatu berdasarkan makna-makna yang ada pada sesuatu bagi mereka, 2) Makna tersebut berasal dari interaksi sosial seseorang dengan orang lain, 3) makna makna tersebut disempurnakan disaat proses interaksi sosial berlangsung (Basrowi dan Soenyono, 2004: 114). Dalam interaksi terjadi proses penyesuaian timbal balik yang bisa menghasilkan suatu aksi khusus berupa "joint action". Dalam teori Blumer, hal itu disebut proses "a positive shaping process in its own right" (Veerger, 1983: 226). Memahami makna yang hadir dalam realitas praktik budaya, juga berarti memahami makna dikonstruksi, diyakini, dan diwariskan. Upaya pengkajian terhadap konstruksi makna ini menjadi bagian yang penting dalam upaya pelestarian praktik budaya terkait dengan penguatan identitas kelompok.

\section{Praktik Budaya Islam di Aceh}

Di antara beberapa warisan budaya yang masih rutin diamalkan di pedesaan Aceh Besar adalah ritual pada perkawinan, kelahiran, dan kematian. Ketiga hal ini telah memiliki pola dan menjadi sesuatu yang lazim dijalankan dengan beberapa perbedaan yang bersifat teknis. Selain itu, terdapat beberapa praktik budaya lainnya. Beberapa praktik itu akan diuraikan di bawah ini. 


\section{Lembaga Adat Gampong}

Salah satu praktik budaya yang masih eksis adalah keberadaan dan berfungsinya lembaga adat di sebagian Gampong di Aceh Besar. Struktur organisasi lembaga adat meliputi Geuchik (kepala desa), Tgk. Imuem (Pimpinan keagamaan yang juga menjadi imam masjid), Tuha Peut (beberapa orang yang dituakan yang berfungsi seperti DPR di pemerintahan), dan Keujreun Blang (lembaga adat yang mengat ur urusan pertanian), Pawang Laot (yang mengatur urusan terkait dengan laut) dan Haria Peukan (yang mengatur urusan terkait dengan hutan). Berdasarkan otoritas Qanun Aceh, saat ini, Lembaga Adat Gampong memiliki kewenangan untuk melakukan peradilan adat gampong terkait penyelesaian damai beberapa sengketa non kriminal yang terjadi di desa ini. Perangkat adat berfungsi dengan baik dibawah kepemimpinan Geuchik.

Salah satu contoh kasus adat yang diputuskan pada peradilan adat adalah kasus pertengkaran warga di Gampong BK. Dalam kasus ini, seorang pemuda (A) yang menjaga rumah keluarganya yang sedang menunaikan ibadah haji, tanpa sengaja, ketika mengendarai sepeda motor hampir menabrak (B) yang menyebabkan (B) terjatuh. Pada saat kejadian itu, keduanya tidak banyak bicara, tetapi kemudian (B) yang masih memendam kesal, mendatangi rumah keluarga (A) dan melempari kaca jendela hingga pecah. Tidak bisa menerima kejadian ini, (A) kemudian mendatangi rumah (B) dengan mengacungkan parang. Namun, pertengkaran ini cepat dilerai masyarakat dan keduanya dihadapkan pada peradilan adat. Setelah mendengarkan kronologi kejadian, perangkat adat memediasikan keduanya untuk berdamai dan saling memaafkan. Pelanggaran adat yang dilakukan harus tetap diberi sanksi yaitu: (B) harus mengganti kaca yang rusak seperti semula hingga selesai pemasangannya, dan (A) karena mengacung parang hingga ke pekarangan lawan dan membuat kerusuhan di gampong dikenai denda memotong kambing Kenduri unt uk dimakan bersama dengan warga dan perangkat adat sebagai simbol permintaan maafnya karena telah membuat keributan. Keluarga (A) menyatakan apresiasinya terhadap keputusan ini dan menurutnya peradilan ini membuatnya merasa nyaman dan mendapat keadilan yang sama meski dia tergolong warga baru di desa ini (Wawancara, Ny. AB di Aceh Besar, Mei 2011).

Contoh lain adalah berupa aturan adat yang mengikat di salah satu gampong pertanian di Aceh Besar. Mereka menetapkan bahwa jika ada seekor ternak sapi atau kerbau yang dilepas begitu saja ke areal persawahan dan mengakibatkan kerusakan lahan atau tanaman, maka sebagai sanksi ke pemiliknya, bintang ternak itu akan dijual. Sebagian hasil diserahkan ke pemiliknya, dan sebagian lain untuk membayar kerugian dan denda. 


\section{Kenduri Moled}

Kenduri Moled adalah kenduri yang dilaksanakan dalam rangka peringatan Maulid Nabi Besar Muhammad SAW pada bulan Maulid (Bulen Moled). Perhitungan Bulen Moled dalam adat ini bukan hanya Bulan Rabi'ul Awwal, tetapi Bulen Moled menurut pemahaman adat ini adalah sepanjang seratus hari dihitung sejak tanggal 12 Rabi'ul Awwal. Meski almanak Hijriah telah memasuki Bulan Jumadil Awal, namun masih disebut Bulen Moled. Kenduri-kenduri Moled pun masih dilaksanakan pada bulan-bulan tersebut. Namun demikian, tetap diyakini bahwa yang lebih baik kenduri tersebut dilaksanakan tepat pada 12 Rabi'ul Awwal atau paling kurang di bulan ini. Menurut beberapa masyarakat, ketetapan serat us hari ini kemungkinan karena memperhitungkan kemampuan masyarakat untuk melaksanakan kenduri karena dulunya sangat tergantung dengan masa panen.

Prosesi kenduri moled dilaksanakan secara serentak oleh seluruh warga di suatu gampong. Penetapan jadwal kenduri moled ini ditetapkan at as musyawarah warga dengan juga memperhit ungkan jangan sampai beradu jadwal dengan peringatan moled di desa-desa di sekitarnya. Dengan sistem repeh uang dan hidangan makanan, kenduri moled ini diselenggarakan dengan semeriah meriahnya. Pada hari yang telah ditetapkan bersama, akan tampak beberapa tahapan kegiatan yang menjadi rangkaian peringatan moled di gampong.

Sejak pagi, rumah-rumah warga disibukkan dengan kegiatan masakmemasak. Untuk keluarga yang tergolong mampu, mereka mengundang saudara, karib kerabat, dan handai tolan untuk makan siang di rumahnya laksana hajatan yang besar. Ada pula yang mengundang anak yatim dan ada yang hanya sekadar masak untuk keluarga dan sumbangan hidangan ke Masjid atau meunasah. Masyarakat meyakini bahwa bersedekah makanan pada peringatan hari lahir Nabi merupakan amalan yang sangat besar, apalagi jika makanan tersebut dimasak sendiri bukan dibeli yang telah siap dari warung atau restoran besar sekalipun. Dalam hal ini, akan lebih besar lagi pahalanya jika sedekah ini dilaksanakan pada malam menjelang 12 Rabi'ul Awwal.

Di masjid atau meunasah ${ }^{1}$ yang menjadi pusat penyelenggaraan kenduri moled ini, sejak subuh telah berkumpul kaum bapak untuk menyembelih hewan

\footnotetext{
${ }^{1}$ Meunasah adalah istilah yang digunakan di Aceh untuk menyebut langgar atau surau. Hanya saja di Aceh fungsi meunasah ini mengandung hirarki politik. Meunasah biasanya menjadi pusat ibadah dan kegiatan untuk level dusun. Dengan demikian, setiap desa memiliki beberapa meunasah dan satu masjid. Biasanya akan terjadi penolakan secara sosial dan politis jika ada suatu komunitas, komplek perumahan misalnya yang bermaksud membangun meunasah lain, karena hanya diizinkan satu meunasah saja untuk satu dusun, kecuali wilayah tersebut telah ditetapkan menjadi dusun.
} 
ternak (kambing atau lembu). Daging kambing atau lembu ini dimasak secara bersama sama menjadi hidangan khas yang disebut "kuah kari" (terdiri dari daging, dengan nangka atau pisang muda). Kuah kari ini dimasak dengan kuali besi yang besar dipimpin oleh 1 atau dua yang ahli memasak kari. Sekitar jam 11 atau 12 siang biasanya "kuah kari" ini telah siap dan telah pula dibagibagikan dalam plastik untuk dibagikan ke seluruh keluarga di desa tersebut. Sebagiannya disimpan untuk kenduri sore dengan para tamu desa. Masyarakat akan datang sendiri ke masjid atau meunasah untuk mengambil "kuah kari" yang menjadi bagian mereka.

Pada siang hari moled, tampak pemandangan yang meriah di jalan-jalan desa. Banyak warga dan tamu yang datang silih berganti untuk memenuhi undangan kenduri moled di rumah handai tolan mereka yang ada di desa tersebut. Kendaraan para tamu yang terparkir di sana-sini menjadi kemeriahan tersendiri yang secara sosial menjadi kebanggaan gampong at as kemeriahan moled yang dilaksanakan.

Selain itu, sejak pagi hingga sore hari suara pengajian al-Qur'an ataupun lagu-lagu Islami terus berkumandang dari masjid atau meunasah yang terdengar hingga ke seluruh desa. Bahkan, manakala desa memiliki kemampuan ekonomi yang lebih, tidak jarang panitia mengundang kelompok profesional pembaca shalawat, atau dalail khairat ${ }^{2}$ yang terus-menerus menampilkan bacaan-bacaan Islami secara nonstop 12 jam bahkan 24 jam.

Pada sore hari, selesai salat Ashar, pusat kenduri moled adalah di masjid atau meunasah. Desa penyelenggara menjadi tuan rumah untuk menyambut tamu-tamu resmi dari desa-desa lain yang diundang. Di halaman masjid atau meunasah telah dibentangkan tikar-tikar dan papan nama desa menurut jumlah desa yang diundang. Di atas satu bagian tikar telah disusun hidangan lengkap untuk satu desa. Satu hidangan itu disusun kira-kira untuk 15 orang. Para tamu terdiri dari perangkat desa lain yang akan datang menurut jumlah permintaan desa penyelenggara dalam undangan, dan mereka duduk pada tikar yang telah ditentukan. Baru kemudian dipersilakan untuk makan bersama. Setiap desa akan merasa sangat bangga jika sanggup mengundang lebih banyak tamu. Hidangan ini disusun berdasarkan sumbangan hidangan masyarakat ditambahkan dengan kuah kari yang telah dimasak bersama.

Puncak acara moled adalah ceramah moled dilaksanakan setelah salat Isya di halaman masjid atau meunasah. Panitia hanya mempersiapkan mimbar untuk

\footnotetext{
${ }^{2}$ Seni tradisional Aceh yang dibawakan oleh sekelompok laki-laki yang menyanyikan syairsyair Aceh, shalawat dan pesan pesan Islami dalam irama khas.
} 
penceramah dan tempat untuk duduk perangkat desa. Sementara itu, masyarakat yang datang mengikuti ceramah tersebut, datang dengan membawa tikar, snack, dan minuman sendiri. Semua duduk di alam terbuka di halaman masjid dan mengikuti kegiatan ceramah yang berlangsung tiga jam, mulai pukul 21.00 sampai pukul 24.00.

Demikianlah prosesi kenduri moled yang masih dijalankan. Namun demikian, ada juga yang mulai lunt ur dalam rangkaian pelaksanaan kenduri moled ini. Pada era 80-an di Pedesaan Aceh Besar ini masih berlaku tradisi kenduri moled di rumah mempelai perempuan (dara baroe). Kenduri ini menyediakan hidangan khusus untuk mempelai laki-laki (linto baroe). Hidangan khusus ini disebut dengan idang meulapeh (hidangan bertingkat). Hidangan semacam ini, hanya disediakan satu kali selama perkawinan kedua mempelai berlangsung. Namun sekarang hal ini sudah jarang dilakukan.

\section{Kenduri Puasa (Meugang)}

Kenduri puasa dilaksanakan untuk menyambut datangnya bulan Ramadhan. Hal itu biasanya disebut dengan uroe meugang puasa. Ada dua istilah yang dikenal terkait uroe meugang puasa ini, yaitu uroe meugang pegawai dan uroe meugang umum. Uroe meugang pegawai biasanya dilakukan dua hari sebelum hari pertama puasa. Pada hari itu, para pegawai telah melaksanakan kenduri di rumahnya dengan makan bersama keluarga besarnya. Adapun uroe meugang umum adalah kenduri yang dilaksanakan satu hari sebelum hari pertama puasa. Tidak diketahui alasan munculnya dua katagori kenduri uroe meugang puasa ini, namun hal tersebut tetap berjalan hingga saat ini.

\section{Adat Pemberian dan Pengembalian Mahar}

Mahar adalah sejumlah emas yang diserahkan pihak calon mempelai lakilaki kepada mempelai perempuan pada saat melamar. Emas yang diserahkan pada saat melamar jumlahnya setengah dari total jumlah mahar yang semestinya diberikan. Bila maharnya 16 mayam, ${ }^{3}$ maka pada saat melamar diberikan 8 mayam, selebihnya diserahkan kepada mempelai perempuan pada hari akad nikah. Namun, tradisi kewajiban menyerahkan mahar setengah dari jumlah mahar yang seharusnya kini sudah mulai bergeser dan tidak terlalu kaku. Pihak mempelai laki-laki dapat menyerahkan sekadar tanda (sebagian mahar) sesuai

\footnotetext{
${ }^{3}$ Mayam adalah satuan takar emas yang lazim digunakan di Aceh. Satu mayam terdiri dari 3 gram emas. Untuk beberapa kabupaten di Aceh seperti Pidie, mahar yang sering berlaku adalah berkisar 16-17 mayam. Yang lebih dari jumlah tersebut lazimnya menjadi kebanggaan dan sebaliknya yang kurang dari jumlah tersebut merasa malu.
} 
dengan kemampuan calon mempelai laki-laki, terutama untuk lamaran dari calon mempelai laki-laki yang berasal dari wilayah atau daerah lain meskipun masih berada dalam wilayah Provinsi Aceh.

Apabila salah satu pihak mengundurkan diri setelah pertunangan dilaksanakan, maka dikenakan sanksi. Bila pihak laki-laki yang mengundurkan diri, sanksinya adalah tidak dikembalikannya mahar yang sudah diserahkan kepada pihak perempuan. Sebaliknya, jika perempuan yang memutuskan pertunangan, maka ia harus mengembalikan 2 (dua) kali jumlah mahar yang pernah diterima. Tujuan pemberian sanksi ini adalah untuk melestarikan pertunangan hingga ke mahligai pernikahan sehingga masing-masing pihak tidak begitu saja memutuskan tali pertunangan yang sudah dirajut bersama.

Perbedaan jumlah pengembalian antara laki-laki dan perempuan yang mengundurkan diri dari ikatan ini untuk tujuan sama-sama mendapatkan sanksi yang adil. Sebagai contoh, seorang laki-laki yang telah memberi mahar 8 mayam emas, kemudian dia mengundurkan diri, maka 8 mayam itu hangus tidak boleh diminta lagi dan dianggap menjadi sanksi baginya. Sementara itu, jika perempuan yang mundur maka dia berkewajiban mengembalikan dua kali lipat, maksudnya 8 mayam unt uk pengembalian mahar yang diterimanya dan 8 mayam lagi sebagai sanksi baginya karena membatalkan perjanjian. Pada intinya, sama-sama menerima sanksi membayar 8 mayam emas.

\section{Intat Boh Kayee dan Ba Meulinum}

Intat Boh Kayee dan Ba Meulinum adalah dua peristiwa yang dilakukan pada saat istri hamil. Intat boh kayee dilakukan saat usia kehamilan istri berusia 4 (empat) bulan. Pada saat itu, keluarga dari pihak suami datang mengunjungi menant unya di rumahnya dengan membawa hidangan yang terdiri dari beragam buah-buahan dan penganan ringan khas Aceh Besar. Hal itu merupakan bentuk kepedulian dari keluarga suami terhadap menant unya yang sedang hamil empat bulan. Keluarga dari pihak suami akan malu jika tidak melakukannya karena khawatir dianggap tidak tahu adat, dan mereka juga mengkhawatirkan anaknya (suami atau linto baro) kehilangan muka di hadapan keluarga istrinya. Apalagi mereka tinggal di keluarga istri.

Ba meulinum dilakukan saat usia kehamilan istri sudah 7 (tujuh) bulan. Pada saat itu, keluarga dari pihak suami datang membawa penganan berupa sejumlah makanan (seperti nasi dan lauk-pauk), buah-buahan, dan makanan ringan khas Aceh untuk dimakan secara bersama oleh rombongan yang datang, keluarga pihak istri, dan undangan serta perangkat adat dari desa tempat tinggal istri. Hal ini juga bertujuan menunjukkan kepedulian dan perhatian dari pihak 
keluarga suami dan sekaligus memberi semangat kepada dara baroe yang telah hamil tujuh bulan. Pada saat itu, juga terjadi prosesi pengungkapan harapan dan dari pihak keluarga suami, dan diikuti dengan penjelasan kondisi dara baroe dari pihak keluarga istri yang biasanya diwakili oleh tokoh adatnya. Selanjutnya, diikuti dengan do'a bersama untuk kesehatan dan keselamatan ibu dan janin. Adat semacam ini merupakan salah satu tradisi yang masih berlaku dan dijalankan masyarakat Pedesaan Aceh Besar sejak dulu hingga kini.

\section{Pemberian Hareuta Peunulang}

Hareuta peunulang adalah pemberian orangtua yang masih hidup kepada anak perempuan yang sudah menikah di hadapan perangkat desa saat anak perempuannya memisahkan tempat tinggal (peumeungkleh) dengan orang tuanya (Nursiti dkk., 2008: 119). Pemisahan tempat tinggal ini dilakukan lazimnya setelah lahir anak pertama atau setelah usia perkawinan mereka mencapai satu tahun. Praktik budaya ini merupakan ketentuan adat yang ditetapkan sejak masa Kerajaan Aceh Darussalam masa kepemimpinan Ratu Safiatuddin. Adat ini ditetapkan dengan Qanun Mekeuta Alam yang di antaranya mengat ur tentang pemberian hareuta peunulang dan menetapkan bahwa mempelai pria harus menetap di rumah istri selama minimal satu tahun.

Bentuk hareuta peunulang ini sangat beragam, bisa dalam bentuk benda bergerak atau tetap (tidak bergerak). Biasanya jenis benda yang dijadikan hareuta peunulang di kalangan masyarakat Aceh dapat berupa tanah, rumah, emas, kebun kelapa, perabot rumah/peralatan dapur, dan binatang ternak. Hareuta peunulang diserahkan oleh orangtua kepada anak perempuannya yang masih berstatus pengantin baru (dara baroe). Penyerahan dilakukan melalui rapat keluarga plus perangkat desa dengan menghadirkan semua anak-anak dan keluarganya. Dalam musyawarah tersebut, Bapak menyampaikan keinginannya kepada anggota keluarga yang hadir bahwa ia ingin menyerahkan hareuta peunulang kepada saudara perempuan mereka (dara baroe). Harta yang diserahkan tersebut dijelaskan di depan hadirin bentuk, jumlah, letak, dan waktunya. Pemberitahuan ini dalam sebuah musyawarah untuk menghindari timbulnya perselisihan antarsaudara atau ahli waris di kemudian hari.

Dalam perkembangannya, penyerahan hareuta peunulang ini dibarengi dengan dokumen tertulis dan disaksikan oleh perangkat desa seperti geuchik, tuha peut, teungku imeum, dan pemangku adat lainnya. Namun, masih ditemukan beberapa orangtua yang tidak melakukannya secara tertulis dan tanpa disaksikan oleh perangkat Gampong. Ketentuan perlunya dokumentasi tertulis didasarkan pada banyaknya kasus sengketa antarahli waris terhadap 
harta yang tidak lagi merupakan bagian warisan karena telah diserahkan kepada anak perempuan tadi (Nursiti dkk., 2008: 123).

Pemberian hareuta peunulang bagi istri oleh orang tua/ keluarga mempelai perempuan merupakan salah satu bentuk kearifan lokal yang sensitif terhadap kepentingan perempuan, terutama bila sewaktu-waktu suami menceraikan istrinya. Dalam kondisi ini, perempuan telah memiliki potensi ekonomi. Tradisi ini sekaligus memberikan peningkatan nilai tawar bagi istri dalam keluarga di hadapan suaminya. Peningkatan nilai tawar ini dapat mengimbangi posisi suami dalam sebuah perkawinan atau rumah tangga. Dalam banyak kasus, jika tidak ada posisi tawar semacam ini, maka terjadi kekerasan dan kesewenangwenangan suami dan juga keluarga suami terhadap istri.

\section{Konstruksi Makna Budaya Islam}

Terkait konstruksi makna, ada tiga point pembahasan yang merupakan pilar kunci pada konstruksi praktik budaya di wilayah pedesaan Aceh Besar. Tiga pilar tersebut meliputi: pertama, proses konstruksi melalui transfer nilai antargenerasi, kedua, meunasah atau masjid sebagai sentra media penyeragaman makna yang membangun dan mempertahankan common meaning, dan ketiga, feed back sosial sebagai efek yang mengikat partisipasi masyarakat.

\section{Transfer Nilai Antargenerasi}

Keberagaman fungsi dan peran yang dibutuhkan dalam penyelenggaraan praktik budaya memberi akses yang luas bagi masyarakat untuk terlibat, termasuk anak-anak dan remaja. Keterlibatan dalam fungsi dan peran tertentu bagi anak-anak dan remaja merupakan proses transfer nilai dalam memaknai praktik budaya meski pemaknaan ini masih terbatas pada fungsi dan perannya saja. Pada kenduri moled misalnya, anak laki-laki mendapat kesempatan untuk bisa ikut dengan rombongan kaum bapak yang diundang untuk menghadiri kenduri moled di gampong yang lain. Dalam proses pendidikan non formal di pengajian, ikut pergi kenduri moled (juga kenduri lainnya) menjadi reward yang diberikan tengku kepada santri laki-laki yang berprestasi. Adapun anak-anak perempuan, meski tidak mendapat kesempatan kenduri seluas anak-laki laki, tetapi keterlibatan mereka dalam kegiatan gotong-royong memasak bersama kaum ibu memberikan kesenangan tersendiri. Kesempatan berkumpul bersama anakanak yang lain di sekitar kaum ibu yang memasak, merupakan keceriaan yang selalu tampak pada saat-saat persiapan praktik budaya yang melibatkan orang yang lebih banyak. Keterlibat an anak perempuan yang lainnya adalah sebagai penari Ranup Lampuan, yaitu tarian tradisional Aceh yang biasanya ditampilkan 
untuk menyambut tamu. Sementara itu, anak laki-laki menampilkan tarian seudati, dalail, atau kesenian tradisional lainnya.

Peluang peran yang terbuka bagi anak-anak dalam praktik budaya inilah yang menjadi salah satu pilar yang mempertahankan dan mewariskan konstruksi makna dalam praktik budaya. Simbol dan pola yang berlangsung dalam praktik budaya terekam secara simultan pada diri anak, termasuk bagaimana orangorang dewasa memaknai, memberi apresiasi dan menjalannkannya.

\section{Sentra Media Penyeragaman Makna}

Di Aceh Besar ini, yang sangat spesifik dari praktik budaya adalah sifat keterpusatannya pada meunasah atau masjid sebagai sentral kendali. Meunasah atau masjid dalam konteks ini tidak dimaknai sebagai gedung atau tempat, tetapi sebagai fungsi yang menyatukan antara misi keagamaan dengan tugas sosial kemasyarakatan. Pemusatan ini dapat dipetakan dalam keterlibatan 'tengku imeum meunasah atau perangkat adat lain dengan fungsi religious leader hampir di semua praktik budaya. Keterlibatan ini terkait dengan pemberian makna sakral dalam pola praktik budaya yang dimaknai masyarakat dan terkait dengan internalisasi dan sosialisasi makna.

Terkait pemberian makna sakral secara spesifik dapat dicontohkan bahwa ruh praktik budaya di pedesaan Aceh Besar ini adalah selalu tentang pemohonan pemberkatan Allah terhadap sesuatu peristiwa atau materi. Kesempurnaan pemberkatan ini adalah dalam otoritas tengku atau religious leader lainnya. Instrumen pemberkatan yang digunakan beragam tergant ung jenis praktik budaya. Bluekat (ketan kuning) dan dedaunan untuk peuseujeuk merupakan instrumen yang melekat hampir di semua praktik budaya.

Terkait dengan internalisasi dan sosialisasi makna, maka tengku dengan meunasah sebagai pusat internalisasi dan sosialisasi, berfungsi membangun common meaning masyarakat. Sebagai contoh dalam kegiatan majlis taklim, baik anak anak, kaum ibu atau kaum bapak, praktik-praktik budaya ini mendapatkan bahasa agama dengan berbagai penekanan. Terkait kenduri moled, kewajiban terhadap anak yang baru lahir, pernikahan dan yang lainnya. Dengan demikian simbol-simbol berpola yang dijalankan dalam praktik budaya mendapat ruang yang luas untuk diperkuat dan disosialisasikan melalui kelompokkelompok pengajian.

Poloma (2004: 259) mengutip pernyataan Blumer:

“Aktor memilih, memeriksa, berpikir, mengelompokkan, dan mentransformir makna dalam hubungannya dengan situasi dimana dia ditempatkan dan arah tindakannya. Dan transformer makna yang selalu kuat adalah "makna" dengan 
kekuatan agama. Durkheim menyebutkan hubungan antara agama dengan masyarakat salah satunya terlihat pada ritual. Menurutnya, kesatuan masyarakat pada masyarakat tradisional, sangat tergantung kepada "hati nurani kolektif" (collective conscience), dan agamalah yang memainkan peran ini. Masyarakat menjadi "masyarakat" karena fakta bahwa para anggotanya taat kepada kepercayaan dan pendapat bersama. Ritual yang terwujud pada pelaksanaan upacara keagamaan, menjadi bukti kepercayaan mereka atas tatanan moral yang ada."

\section{Feed Back sebagai Sosial Effect}

Pilar ketiga yang menjadi bagian penting dalam konstruksi praktik budaya di komunitas ini adalah feed back sebagai social effect. Feed back dan social effect ini terkait dengan motivasi dan partisipasi masyarakat mengikuti praktik budaya. Dengan spirit agama sebagaimana dijelaskan di atas, sebenarnya sudah menjadi dasar yang kuat bagi masyarakat untuk mengambil peran dalam praktik budaya. Namun, pada kelompok masyarakat yang kurang memiliki spirit agama ini, social effect memegang peran yang penting.

Dengan intensitas praktik budaya yang rutin dijalankan, maka ketergantungan masyarakat satu sama lain menjadi sangat kuat. Sistem balance juga tampak tegas dalam komunitas ini. Sebagai contoh, si A yang kerap tidak hadir pada undangan gotong-royong praktik budaya tertent $u$ di masyarakat, biasanya akan mendapat hal yang sama jika ia memiliki hajatan praktik budaya tertentu, sebagai effect sikap acuhnya.

Dalam pelaksanaan praktik budaya, pihak penyelenggara akan menyampaikan undangan secara lisan, door to door dengan kejelasan status undangan apakah sebagai tamu saja atau juga terlibat dalam membantu persiapan. Yang diminta membantu biasanya akan merasa sangat dihargai karena dianggap orang yang dekat dengan keluarga penyelenggara, sehingga jika ada yang diminta bantuannya tetapi tidak datang tampa alasan yang jelas, maka kecenderungan untuk mendapat balasan yang sama sering terjadi.

Feed back-social effect ini akhirnya menjadi sistem kontrol yang mengikat konstruksi makna pada praktik budaya dengan simpul yang kuat. Hal ini diperkuat lagi dengan adanya regulasi yang memberi kewenangan adat terhadap perangkat adat gampong, dan pembinaan kehidupan adat.

\section{E. Simpulan}

Aceh Besar masih memiliki budaya Islam yang bertahan sampai sekarang, yakni Lembaga Adat Gampong, Kenduri Moled, Kenduri Puasa (Meugang), adat Pemberian dan Pengembalian Mahar, Intat Boh Kayee dan Ba Meulinum, 
dan Pemberian Hareuta Peunulang. Praktik budaya yang masih berjalan kuat hingga saat ini disebabkan tiga pilar konstruksi yang aktif berperan dalam komunitas ini. Pertama, proses konstruksi melalui transfer nilai antargenerasi. Kedua, meunasah atau masjid sebagai sentra media penyeragaman makna yang membangun dan mempertahankan common meaning. Ketiga, feed back sosial sebagai effect yang mengikat partisipasi masyarakat.

\section{Daftar Pustaka}

Atjeh, Aboe Bakar. 1980. "Tentang nama Aceh", dalam Ismail Suny (Ed.), Bunga Rampai Tentang Aceh. Jakarta: Aksara.

Berger, L. Peter. 1985. Humanisme Sosiologi. Jakarta: Inti Sarana Aksara. Giddens, Anthony. 1986. Kapitalisme dan Teori Sosial Modern: Suatu Analisis Karya-Tulis Marx, Durkheim, dan Max Weber, terj. Soeheba Kramadibrata. Jakarta: UI-Press.

Iskandar, T. 1972. "Hari Depan Kebudayaan Aceh", Makalah dalam Seminar Kebudayaan, PKA II dan Dies natalis Unsyiah XI, Banda Aceh.

Basrowi, Muhammad dan Soenyono. 2004. Teori Sosial dalam Tiga Paradigma. Surabaya: V de Press.

Ibrahim, Muhammad dan Rusydi Sufi. 1987. "Proses Islamisasi dan Munculnya Kerajaan-kerajaan Islam di Aceh”, dalam A. Hasjmy. Sejarah Masuk dan Berkembangnya Islam di Indonesia. Bandung: al-Ma'arif.

Nursiti, dkk. 2008. "Menyanding Cedaw dengan Hukum Positif, Hukum Adat, dan Hukum Islam di Aceh". Hasil Penelitian. Aceh Besar: T.P.

Poloma, Margareth M. 2004. Sosiologi Kontemporer, Terj. Tim Yasogama. Jakarta: Raja Grafindo Persada.

Tim May and Jason L. Powell. 2008. Situating Social Theory, Second Edition. New York: The McGraw-Hill Companies.

Veeger, K.J. 1983. Realitas Sosial refleksi Filsafat Sosial atas Hubungan Individu, Masyarakat dalam Cakrawala Sejarah Sosiologi. Jakarta: Gramedia. 